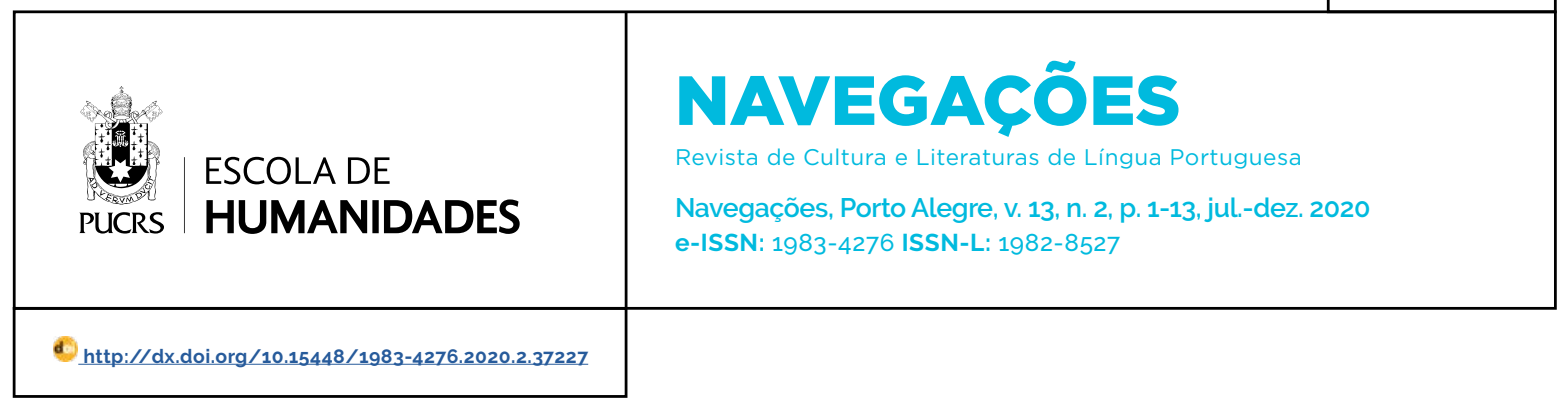

ENSAIOS

\title{
Linguagem mitopoética e reapresentação ética da história em Terra Sonâmbula, de Mia Couto
}

\author{
Mythopoetic language and ethical re-presentation of history in Sleepwalking Land, by \\ Mia Couto
}

\section{Fabiana Nicoli Dias ${ }^{1}$ \\ orcid.org/0000-0002-0695-8004 \\ fabiananicolio8@gmail.com \\ Fabiola Simão Padilha \\ Trefzger $^{1}$ \\ orcid.org/0000-0002-6361-7134}

fabiolapadilha27@gmail.com

Recebido em: 6/3/2020

Aprovado em: $2 / 6 / 2020$

Publicado em: 25/2/2021

\section{(c) (1)}

Artigo está licenciado sob forma de uma licença Creative Commons Atribuicão 4.0 Internacional.
Resumo: Propõe-se, neste artigo, o exame da linguagem mitopoética enquanto alternativa esteticamente ética para a recriação ficcional da realidade histórica de guerra civil moçambicana em Terra Sonâmbula (1992), de Mia Couto. Com o fito de alcançar nosso objetivo, partimos da definição de mitopoética, de Eleazar Mielietinski (1987), e dos estudos sobre a história, considerando ainda sua interface com a literatura e suas implicações éticas e estéticas conforme postulados de Theodor W. Adorno (1993), Walter Benjamin (1994) e Michel de Certeau (1982). A poética do mito é constituida, no romance, como linguagem avessa à concepção positivista de história evolutiva por colaborar para a articulação e o confronto entre mito e história, oralidade e escrita, poesia e prosa e língua portuguesa e linguas moçambicanas em prol da construção de uma narrativa que recria os mundos sobrepostos da Moçambique pós-independência.

Palavras-chave: Ética. Estética. Linguagem mitopoética. Mia Couto. Terra Sonâmbula.

Abstract: It is proposed, in this article, to examine the mythopoetic language as an aesthetically ethical alternative to the fictional recreation of the historical reality of mozambican civil war in Sleepwalking Land (1992), by Mia Couto. In order to achieve our objective, we use as a starting point the definition of mythopoetics, by Eleazar Mielietinski (1987), and the studies about history, considering its interface with literature and their ethical and aesthetic implications, according to postulates of Theodor W. Adorno (1993), Walter Benjamin (1994) and Michel de Certeau (1982). The mythopoetic is constituted, in the novel, as a language averse to the positivist conception of evolutionary history, as it contributes to the articulation and confrontation between myth and history, orality and writing, poetry and prose and portuguese language and mozambican languages in favor of constructing a narrative that recreates the overlapping worlds of post-independence Mozambique.

Keywords: Ethic. Aesthetics. Mythopoetic language. Mia Couto. Sleepwalking Land.

Em Terra Sonâmbula, de Mia Couto, o menino Muidinga e o velho Tuahir encontram, em um ônibus queimado e suas redondezas, um lugar para se instalarem em meio ao contexto de guerra civil moçambicana. Ao lado de um corpo e por entre os destroços provocados pelas chamas, as personagens se deparam com os cadernos de Kindzu, outra vítima do horror da guerra, dentro de uma mala. Contrariando as intenções de Tuahir, Muidinga conserva os escritos e não deixa o mais velho queimá-los. Alternando entre a narração atual, em terceira pessoa, das aventuras de Muidinga e Tuahir pelos arredores do ônibus e o enredo, em primeira pessoa, dos escritos e memórias do passado de Kindzu, o romance é 
costurado com interpenetrações de um plano no outro por uma carpintaria poética vinculada à narrativa mítica. Tendo em vista essas duas linhas narrativas, as pesquisadoras Tania Macêdo e Vera Maquêa (2007, p. 60-61) argumentam que

[...] Os narradores já não têm histórias individuais para contar a não ser a história que os enreda a todos na mesma malha de miséria e sofrimento bordada com as sombras da morte que ronda a todos naquele lugar. O que seria uma narrativa oral e outra escrita, o presente e o passado, o próximo e o distante, o menino Muidinga e o velho Tuahir, um Moçambique ancestral e um pais construido a partir do modelo do estado ocidental, revela-se aos poucos na farsa de uma dualidade.

Pela dissolução e, ao mesmo tempo, confrontamento de tais dualidades, Mia Couto produz um romance - publicado em 1992, ano de fim da guerra civil moçambicana - que reinventa não só essa mesma guerra, mas todo o contexto de um país em convulsão, cujas terras sonambulantes vagueiam em busca dos sonhos de uma Moçambique futura. Na narrativa, a escrita da história implica, portanto, um posicionamento político frente à sobreposição dos mundos diversos e nem sempre compativeis que permeiam a Moçambique contemporânea.

A concepção tradicional de que a escrita historiográfica é capaz de realizar uma transposição exata pela linguagem dos fatos do passado corrobora a compreensão da história como cortejo triunfal do progresso, com que rompe Walter Benjamin. O autor, em suas teses "Sobre o conceito de História", promove a ruptura para com a visão positivista de uma História Universal. $\mathrm{O}$ posicionamento teórico de Benjamin se encontra na esteira do que o historiador Michel de Certeau (1982, p. 67) chamou de primeira crítica do cientificismo, que, na primeira metade do século $X X$,

[...] desvendou na história "objetiva" a sua relação com um lugar, o do sujeito. Analisando uma "dissolução do objeto" (R. Aron), tirou da história o privilégio do qual se vangloriava, quando pretendia reconstituir a "verdade" daquilo que havia acontecido. A história "objetiva", aliás, perpetuava com essa idéia de uma "verdade" um modelo tirado da filosofia de ontem ou da teologia de ante-ontem; contentava-se com traduzi-la em termos de "fatos" históricos... Os bons tempos desse positivismo estão definitivamente acabados.
Posto que ainda é possivel nos depararmos vez ou outra com a defesa desse tipo de perspectiva historiográfica, é de fato importante evidenciar o movimento, que vem sendo promovido pelos próprios historiadores, de deslocamento do lugar da historiografia enquanto discurso unívoco e verdadeiro sobre o passado. Michel de Certeau é apenas um dos historiadores que se propõem a reexaminar o estatuto da História enquanto ciência humana. Nesse sentido, para Benjamin (1994, p. 224), o passado não pode ser conhecido e relatado da maneira como de fato ocorreu, mas articulado historicamente mediante uma relação dialética com o presente. Jeanne Marie Gagnebin (2006, p. 39) evidencia que a busca pela verdade do passado está menos próxima da identificação entre "fatos" e "palavras" do que de uma "ética da ação presente". Ao apontar para a inviabilidade epistemológica da correspondência entre fatos e linguagem, Benjamin denuncia que o factual adquire esse status mediante um discurso científico que o edifica como tal (GAGNEBIN, 2006, p. 40).

O rompimento da visão tradicional de historiografia possibilita entendê-la como uma narração, aproximando-a, de certa maneira e até certo ponto, da literatura. As fronteiras entre discurso historiográfico e discurso literário, anteriormente tão rígidas, tornam-se, assim, menos nítidas. A partir dessa constatação, Gagnebin (2006, p. 41-42) promove questionamentos basilares para a discussão sobre os liames entre história e literatura:

[...] O historiador que toma consciência do caráter literário, até mesmo retórico, narrativo de sua empresa, não corre o risco de apagar definitivamente a estreita fronteira que separa a história das histórias, o discurso científico da ficção, ou ainda a verdade da mentira? E aquele que insiste sobre o caráter necessariamente retrospectivo e subjetivo da memória em relação ao objeto de lembrança, ele também não corre o risco de cair num relativismo apático, já que todas as versões se eqüivalem se não há mais ancoragem possivel em uma certeza objetiva, independente dos diferentes rastros que os fatos deixam nas memórias subjetivas e da diversidade de interpretações sempre possiveis a partir dos documentos existentes?

Michel de Certeau (1982, p. 41) é assertivo ao ressaltar que a mudança no paradigma historiográfico não pressupõe a renúncia da história ao real, mas 
a modificação na relação entre discurso historiográfico e realidade. Não se deve, pois, presumir

[...] o desaparecimento da referência ao real. Esta referência foi, ao invés, deslocada. Ela não é mais imediatamente dada pelos objetos narrados ou "reconstituidos". Está implicada na criação de "modelos" (destinados a tornar os objetos "pensáveis") proporcionados às práticas, pela confrontação com o que lhes resiste, o que os limita e exige outros modelos, finalmente, pela elucidação daquilo que tornou possivel essa atividade inscrevendo-a numa economia particular (ou histórica), da produção social (DE CERTEAU, 1982, p. 53).

Trata-se, logo, menos de uma questão sobre a restituição do real pretérito e mais sobre a ação de torná-lo inteligivel (DE CERTEAU, 1982, p. 53). Sendo assim, a pesquisa elaborada pelo historiador deve ser apresentada no espaço de uma escritura, que, por sua vez, lhe impõe determinados limites (DE CERTEAU, 1982, p. 94). Por um lado, essa escrita é influenciada pelas práticas sociais de que é decorrente e é, ela própria, uma prática social; por outro, "funciona como imagem invertida; dá lugar à falta e a esconde; cria estes relatos do passado que são o equivalente dos cemitérios nas cidades; exorciza e reconhece uma presença da morte no meio dos vivos" (DE CERTEAU, 1982, p. 95).

Na mesma direção, Gagnebin (2006, p. 41) defende a possibilidade de uma referenciação que não se reduza à descrição exata da realidade, mas que se estenda ao processo real que precede a relação entre sujeito e objeto. Dessa forma, o distanciamento tanto do relativismo apático da conversão da história em "oceano de ficção" quanto do positivismo dogmático pode se dar pela escrita da história que busque no passado não o seu estatuto de fato científico, mas sim os rastros por ele deixados (GAGNEBIN, 2006, p. 42). O rastro, assim como a memória, é construido sobre a tensão entre presença e ausência: presença no presente de um passado esvaecido e presença do passado que invade um presente fugaz. Nisso consiste, ao mesmo tempo, a riqueza e a fragilidade da memória e do rastro (GAGNEBIN, 2006, p. 44).

Em Terra Sonâmbula, o esforço da memória de Kinzu se mostra rastro pelo registro:
Quero pôr os tempos, em sua mansa ordem, conforme esperas e sofrências. Mas as lembranças desobedecem, entre a vontade de serem nada e o gosto de me roubarem do presente. Acendo a estória, me apago a mim. No fim destes escritos, serei de novo uma sombra sem voz (COUTO, 2007, p. 15).

É nesse sentido que as pesquisadoras Jane Tutikian e Vivian Ignes Albertoni Silva (2003, p. 90) consideram a escrita dos cadernos de Kindzu, para além de um registro da memória, como tentativa de ordenar o tempo desencontrado do pretérito.

Segundo De Certeau (1984, p. 84), essa relação entre pesquisa historiográfica e rastros já não é construída por uma trajetória que parte das "raridades" do passado com a pretensão de criar uma imagem que o sintetize no presente, mas deriva de uma formalização teórico-científica do presente que confere sentido aos restos do passado, que, por sua vez, lhe resistem a totalidade. A estruturação do discurso recompõe textualmente as referências materiais obtidas do passado e, assim, se constitui enquanto mecanismo que desprende do rastro "uma verossimilhança do relato e uma validade do saber. Ela produz credibilidade" (DE CERTEAU, 1984, p. 101).

Assim, a imagem do passado, furtiva, só se deixa fixar no momento de seu reconhecimento e, portanto, anuncia a possibilidade de seu apagamento irrecuperável por cada presente que não se assume como por ela visado (BENJAMIN, 1994, p. 224). Michael Löwy (2005, p. 62) evidencia como Benjamin busca mostrar a constelação crítica que um estilhaço do passado constrói junto a um dado momento do presente. Dessa forma, recuperar o passado adquire uma dimensão política ativa que estabelece a indissolubilidade entre rememoração e redenção (LÖWY, 2005, p. 62). A rememoração dos corpos espezinhados durante o cortejo do progresso não se resume à mera contemplação da barbárie transcorrida. É somente por meio da busca pela reparação das injustiças passadas e pela efetivação dos objetivos pelos quais os vencidos morreram que a rememoração se associa à possibilidade de redenção no presente e torna inacabada a dor das gerações derrotadas durante o processo histórico (LÖWY, 
2005, p. 51). Essa necessidade é anunciada por Couto em vários momentos do romance, dentre eles quando Kindzu testemunha a retirada de um corpo morto sendo arrastado pela estrada:

[...] Aquele era o funeral que cabia ao anônimo desvalido: poeirando pela rua, as moscas zunzinando, contratadas carpideiras dos ninguéns.

Fiquei a ver os soldados se afastando entre as casas demolidas. O ar estava carregado, ensopado. Ao olhar o fúnebre cortejo, desaparecendo entre os escombros, me veio o pensamento: nós, que nascêramos naquele tempo, éramos os últimos viventes. Depois de nós já não havia mundo para receber mais ninguém (COUTO, 2007, p. 122).

Esse episódio pode ser aproximado ao cortejo descrito por Benjamin na tese nove, em que o anjo da história se vê preso na tempestade do progresso: "Essa tempestade o impele irresistivelmente para o futuro, ao qual ele vira as costas, enquanto o amontoado de ruínas cresce até o céu. Essa tempestade é o que chamamos de progresso" (BENJAMIN, 1994, p. 226).

Segundo Benjamin (1994, p. 224), a articulação histórica do passado implica o apoderamento de uma lembrança "tal como ela relampeja no momento de um perigo". Para Löwy (2005, p. 65),

O momento de perigo para o sujeito histórico - ou seja, para as classes oprimidas (e para o historiador que optou por esse campo) - é aquele em que surge a imagem autêntica do passado. Por quê? Provavelmente porque nesse momento se dissolve a visão confortável e preguiçosa da história como "progresso" ininterrupto. O perigo de uma derrota atual aguça a sensibilidade pelas anteriores, suscita o interesse dos vencidos pelo combate, estimula um olhar critico voltado para a história.

Cada luta do oprimido no presente possui, portanto, o potencial de suscitar a revisitação e indagação das vitórias históricas anteriores. Assim, é desconstruída a imagem unilateral da relação entre o ontem e o hoje em prol da convicção de que rememoramos sob a luz do presente o passado que, iluminado, pode tornar-se força redentora para o tempo de agora (LÖWY, 2005, p. 61).

A visão de história de Benjamin combate aquela baseada na noção de progresso, que possui como norma histórica o avanço da sociedade e para qual as catástrofes históricas são tratadas como exceção à trajetória evolutiva da humanidade. O autor compreende o processo histórico como a permanência desse "estado de exceção", sendo a regra, portanto, a barbárie, a opressão e a violência. Os momentos de barbárie não são parênteses ou desvios da marcha do progresso humano, mas decorrentes dela (LÖWY, 2005, p. 83). Logo, Benjamin (1994, p. 226) constata como insustentável a perspectiva histórica sobre a qual se fundamenta a perplexidade para com o fato de que as catástrofes das guerras do século $X X$ "ainda" fossem possiveis naquele tempo - e não se faz necessário grande pudor para constatar que a declaração do teórico se estende ao século XXI. Faz-se urgente, assim, incitar uma explosão no contínuo da história evolutiva da humanidade. O passado é cheio de "tempos-de-agora", isto é, carregado de momentos atuais que podem ser utilizados como material explosivo no combate contra a história homogênea e vazia que nos conduz à barbárie (BENJAMIN, 1994, p. 229-230). A escrita historiográfica que captura, no passado, a possivel centelha de material explosivo no presente rompe com a ideia de neutralidade positivista que, na verdade, mascara a identificação afetiva entre escritor e vencedor. A história, portanto, precisa ser escovada a contrapelo, ou seja, sua versão oficial deve ser subvertida, assim como a ideia de que a redenção/revolução é fruto inevitável do progresso (LÖWY, 2005, p. 74).

Como já mencionado anteriormente, essa demanda histórica alertada por Benjamin vem sendo considerada, a partir principalmente da segunda década do século XX, por vários pesquisadores em suas práticas historiográficas ${ }^{2}$. Resta saber como essa alteração no paradigma teórico

\footnotetext{
2 Alguns exemplos de obras que tratam sobre essa questão são: A escrita da história: novas perspectivas (1991) e Formas de fazer história (1991), de Peter Burke; A História em Migalhas: dos Annales à nova história (1987) e A história (2000), de François Dosse; O sabor do arquivo (1981) e Lugares para a História (1982), de Arlette Farge; Futuro passado: contribuição à semântica dos tempos históricos (1979) e Estratos do tempo: estudos sobre história (2003), de Reinhart Koselleck; História e Memória (1988) e A história deve ser dividida em pedaços? (2014). de Jacques Le Goff; O pequeno x: da biografia à história (2010), de Sabina Loriga; Como se escreve a história (1971) e História da vida privada (1987), de Paul Veyne.
} 
da História implica, também, a modificação das convenções literárias por meio das quais se recria ficcionalmente, em maior ou menor grau, eventos históricos. Se a tentativa de apreender o passado eticamente pela escrita não está desvinculada da elaboração estética da linguagem, esse compromisso ético não deve ser assumido somente pela historiografia, mas também pela literatura que reapresenta um evento histórico pela ficção.

Theodor W. Adorno (2011, p. 17) evidencia que as obras de arte - e, portanto, a literatura - recusam a empiria e, ao mesmo tempo, não deixam de adotar sempre uma posição frente à realidade empírica à qual pertencem. Dessa maneira,

[...] Que as obras de arte, como mónadas sem janelas, «representem» o que elas próprias não são, só se pode compreender pelo facto de que a sua dinâmica própria, a sua historicidade imanente enquanto dialéctica da natureza e do domínio da natureza, não é da mesma essência que a dialéctica exterior, mas se lhe assemelha em si, sem a imitar (ADORNO, 2011, p. 18).

A autonomia e a historicidade da arte a constituem, assim, em sua ambiguidade. As tensões externas à produção artística são sedimentadas em sua própria configuração estética, ou seja, "retornam às obras de arte como os problemas imanentes da sua forma" (ADORNO, 2011, p. 18). A produção literária pode, portanto, surgir enquanto mônada dessa realidade histórica - ao, simultaneamente, recusá-la e buscar alcançá-la - por uma formulação estética que faculte a reapresentação de vários "tempos-do-agora" do passado rememorado. A reinvenção de um evento histórico mediante a elaboração estética ética possibilita, dessa forma, uma literatura produzida, lida e contada a contrapelo.

Jaime Ginzburg (2010, p. 130) indaga sobre as possiveis maneiras de conciliação na escrita literária entre o empenho para com a memória e o combate do horror histórico. O pesquisador ratifica o que Adorno apresenta em Teoria estética ao constatar a necessidade de a literatura reexaminar seu vínculo com a linguagem frente à barbárie da história. Sendo assim, a manifestação literária por uma linguagem trivial forjaria uma experiência distinta daquela estranha, singulare desumana dos fragmentos do passado recriados pela ficção (GINZBURG, 2010, p. 130). A leitura de literatura possui a potência, segundo Ginzburg (2012, p. 24), de transgredir perspectivas automatizadas da realidade, deslocando maneiras de perceber o mundo. Rever a linguagem que busca comunicar a violência histórica é, portanto, produzir uma literatura cuja leitura pode provocar a quebra da apatia e do entorpecimento em que o mundo contemporâneo se imergiu. O pensamento de Ginzburg não diz sobre uma busca pela utilidade tecnicista da literatura, mas sobre o entendimento da existência literária em uma sociedade cuja formação estética é decisiva para a sua constituição ética (GINZBURG, 2012, p. 25).

Nesse sentido, a comum lapidação poética do mito nas narrativas do século $X X$ pode ser considerada um posicionamento ético de uma construção literária que, segundo Eleazar Mielietinski (1987, p. 3), demonstra a "tomada de consciência da crise da cultura burguesa como crise da civilização em seu conjunto, o que levou à frustração no racionalismo positivista e no evolucionismo, na concepção liberal de progresso social". Para a investigação dessa tendência da literatura, faz-se necessário recorrer a considerações sobre o mito desenvolvidas por estudiosos como Mircea Eliade, Claude Lévi-Strauss, Raphael Patai, Theodor W. Adorno, Max Horkheimer e, como já mencionado, Eleazar Mielietinski. Apesar de apresentarem teorias do mito que se diferem em certa medida, seus postulados elucidam alguns pontos de articulação entre narrativa mítica, linguagem e história.

Mircea Eliade (2013, p. 8) aborda a mudança de acepção atribuida ao termo mythos frente ao despojamento de seus traços religiosos e metafísicos pelos gregos - processo no qual Xenófanes foi pioneiro - em detrimento do pensamento orientado pelo logos racional e, posteriormente, pela História Universal. Dessa forma, o mito passa a designar o que é falso e ilusório, concepção contestada de forma mais contundente a partir do século $X X$, quando os estudiosos aderem à noção vigente nas sociedades arcaicas, para as quais o mito consiste, pelo contrário, em uma 
história verdadeira de caráter exemplar e sagrado (ELIADE, 2013, p. 7). Alinhado a essa perspectiva, o autor salienta a dificuldade da definição do termo devido à sua complexidade cultural e aposta na conceituação que lhe parece menos imperfeita por ser a mais abrangente: "[...] o mito conta uma história sagrada; ele relata um acontecimento ocorrido no tempo primordial, o tempo fabuloso do 'princípio'" (ELIADE, 2013, p. 11). O mito mostra as diversas irrupções do sagrado que fundamentam o mundo da sua atualidade narrativa. De modo semelhante ao homem contemporâneo que se entende como resultado dos acontecimentos históricos, o homem das sociedades arcaicas se concebe como fruto de eventos míticos (ELIADE, 2013, p. 16). Eliade (2013, p. 17) distingue categoricamente o homem arcaico do homem moderno por "[...] a irreversibilidade dos acontecimentos que, para este último, é a nota característica da História, não constitui[r] uma evidência para o primeiro [...]" devido ao seu dever de reatualizar o passado mítico da tribo e não somente resgatá-lo pela memória. Essa diferença pode, no entanto, ser minimizada se considerarmos a rememoração do passado e a sua irrupção no presente - como consta na ideia de articulação histórica pela dialética entre rememoração e redenção, desenvolvida por Benjamin - como uma forma de reatualização.

Claude Lévi-Strauss e Raphael Patai também discutem, cada um à sua maneira, os liames entre mito e história. O primeiro torna as rígidas fronteiras entre um e outra mais turvas ao declarar que, em nossa sociedade, a história substitui, de certo modo, o pensamento mitológico

[...] e desempenha a mesma função, já que para as sociedades sem escrita e sem arquivos a Mitologia tem por finalidade assegurar, com um alto grau de certeza - a certeza completa é obviamente impossivel -, que o futuro permanecerá fiel ao presente e ao passado. Contudo, para nós, o futuro deveria ser sempre diferente. e cada vez mais diferente do presente, dependendo algumas diferenças, é claro, das nossas preferências de carácter político. Mas, apesar de tudo, o muro que em certa medida existe na nossa mente entre Mitologia e História pode provavelmente abrir fendas pelo estudo de Histórias concebidas não já como separadas da Mitologia, mas como uma continuação da mitologia (LÉVI-STRAUSS, 1978, p. 51-52).
Lévi-Strauss (1978, p. 49) diferencia a história da mitologia pelo caráter fechado da segunda em contraposição ao sistema aberto em que consiste a primeira. O teórico indaga sobre a capacidade de desenvolver-se uma história mediante a totalidade científica ou se, de fato, ao procurar fazê-lo, não estariamos criando nossa própria mitologia em busca de uma História pura (LÉVI-STRAUSS, 1978, p. 50). A discussão desenvolvida por Patai consiste na constatação de que o mito, ao contrário do interesse histórico acadêmico positivista, não retorna ao passado para sanar uma curiosidade intelectual, mas para resgatar os decisivos acontecimentos concernentes ao aqui e agora (PATAI, 1974, p. 67). O autor contrapõe categoricamente a postura científica da mitológica diante de uma descoberta. Segundo ele, enquanto o cientista não se atenta aos efeitos de sua conquista para a humanidade, o historiógrafo do mito assinala a importância de sua solução ao homem do presente (PATAl, 1974, p. 68). O encontro entre mito e história se dá pela assimilação de traços desta por aquele. Os fatos históricos, ao serem apropriados pelos mitos, se afastam da precisão e detalhamento pretendidos pela historiografia, são reconstruídos com a adição de contornos fantásticos ou maravilhosos e, concomitantemente, ganham em longevidade e potência de atuação na cultura (PATAI, 1974, p. 72). O pensamento mítico poderia, de acordo com a concepção do teórico, potencializar uma relação outra que não a cientificista entre o homem e o passado.

Theodor W. Adorno e Max Horkheimer, em Dialética do Esclarecimento (1995), apresentam a vivência dialética entre o mito e o esclarecimento - este último orientando a concepção de história tradicional a qual Benjamin contesta - a partir do exame das origens do pensamento filosófico racional ocidental com o surgimento da poesia de tradição épica grega. Em sua leitura da obra dos autores, Jeanne Marie Gagnebin aponta a incapacidade de o conhecimento esclarecido defender-se da barbárie decorrente do progresso histórico e a sua colaboração para esse destino, que é concebida pelos teóricos para além do próprio pensamento baseado no logos racional, 
de forma a vincular-se, portanto, às fontes míticas que o precederam e a partir das quais emergiu (GAGNEBIN, 2006, p. 29). A hipótese central da obra é a de que o mito superado pelo esclarecimento já é fruto do próprio esclarecimento e de que o esclarecimento se reverte, cada vez mais, à mitologia (GAGNEBIN, 2006, p. 29). Ao ser registrado, o mito possui seu caráter de relato abreviado e seu aspecto de doutrina intensificado (ADORNO; HORKHEIMER, 1995, p. 20). Por outro lado, o esclarecimento recebe os conteúdos do mito e, empenhado em destruí-los e refutá-los, acaba por firmar-se na própria esfera mitológica (ADORNO; HORKHEIMER, 1995, p. 22). Adorno e Horkheimer produzem um texto cuja hipótese se fundamenta, portanto, na compreensão de que razão e dominação se relacionam fortemente (GAGNEBIN, 2006, p. 29). No entanto, Gagnebin desenvolve uma pertinente crítica ao pensamento exposto pelos autores, apesar de não deixar de conferir-lhe o devido êxito. Para a pesquisadora, podemos "pensar melhor os potenciais da imaginação e da fantasia humanas que não se esgotam na alternativa aporética da dominação mítica versus dominação racional" apresentada por Adorno e Horkheimer (GAGNEBIN, 2006, p. 31).

Como, dessa forma, pensar na articulação entre mito e história sem que o primeiro se mostre a exata imagem invertida do pensar esclarecido que propiciou uma concepção de História Universal evolutiva que nos conduz em direção à catástrofe? Como pensar na elaboração estética do mito pela poesia enquanto um posicionamento ético frente à recriação da história ao encarar o conhecimento mítico como o irmão menos atraente de uma perspectiva histórica que marcha pelo tempo homogêneo e linear do progresso? Como explorar as potencialidades da imaginação e fantasia humanas, sobre as quais Gagnebin comenta, sem esbarrar na contradição entre mito e história, a todo momento posta a nós? O estudo sobre a poética do mito, desenvolvido por Mielietinski, é particularmente elucidativo, nesse sentido, devido o autor constatar a necessidade de compreender-se o processo de "remitologização" na literatura e na cultura do século XX - sobre o qual iremos comentar de maneira mais detida - relacionando as formas arcaicas do mito com a realidade histórica que as propiciou e confrontando o mito primitivo com a mitologização em um contexto contemporâneo que o reinventa (MIELIETINSKI, 1987, p. 5). Segundo Bosi (1983, p. 151), o mito se depara, de maneira não tão esporádica, com faces conservadoras de alguma ideologia com propensões inclinadas a grupos dominantes. No entanto, quando "cruza o limiar do poema", ele pode retomar a inocência extraviada pela sua apropriação para com um posicionamento ideológico reacionário (BOSI, 1983, p. 153). Apostamos, por meio desta pesquisa, que o mesmo pode acontecer quando a mitopoética cruza as fronteiras do romance.

A poética do mito é examinada por Eleazar Mielietinski baseada na acepção assumida pelo termo mediante a produção literária desenvolvida por alguns escritores do século XX (Joyce, Kafka, Yeats, Eliot, O' Neil e outros) como um meio de organização da composição artística e manifestação literária de modelos culturais relativamente estáveis. Segundo o estudioso, a arte herdou do mito a metaforicidade e o sincretismo entre o pensamento mítico-religioso e as perspectivas filosóficas que o superaram (MIELETINSKI, 1987. p. 1). À recorrente repetição de protótipos mitológicos com distintas roupagens como uma tentativa de escritores do século XX de mitologizar a narrativa do cotidiano e à tendência dos críticos de revelar a base mitológica de obras literárias, Mielietinski (1987, p. 2) denomina "mitologismo" ou ainda "remitologização" da literatura e cultura do século XX. Segundo o autor,

[...] a história da cultura esteve, de uma forma ou de outra, em correlação com a herança mitológica dos tempos primitivos e da Antiguidade. essa relação oscilou fortemente, mas no conjunto a evolução ocorreu no sentido da "desmitologização" (cujo apogeu pode ser considerado o iluminismo do século XVIII e o positivismo do século $X I X)$ e no século $X X$ deparamos com uma súbita "remitologização" (pelo menos em termos de cultura ocidental) que, pela envergadura, supera consideravelmente a paixão romântica pelo mito no começo do século XIX e se opõe ao processo de desmitologização do seu conjunto (MIELIETINSKI, 1987, p. 4). 
O processo de mitologização da literatura e da crítica literária caracteriza o que se convencionou chamar de modernismo - embora não se resuma a ele - e substitui o realismo tradicional do século XIX, que prezava por uma "representação fiel" da realidade de seu tempo. Esse movimento da cultura resulta em grande parte, como já comentado, da crise do pensamento burguês e, portanto, do conhecimento ocidental, orientado pelo positivismo e racionalismo (MIELIETINSKI, 1987, p. 3). O mitologismo está estreitamente vinculado ao olhar desiludido do homem frente ao historicismo, ao temor diante do horror histórico e ao ceticismo perante a esperança de mudança (MIELIETINSKI, 1987, p. 353). Dai decorre a inclinação dos escritores e críticos à transgressão dos limites histórico-sociais e espaço-temporais com a finalidade de alcançar o "conteúdo universalmente humano" (MIELIETINSKI, 1987, p. 4). O mito se mostra, devido à sua tradicional configuração simbólica, a linguagem apropriada para a comunicação de paradigmas "eternos" do âmbito individual e social (MIELIETINSKI, 1987, p. 4). O mitologismo se institui, logo, como elemento de estruturação da própria narrativa pela execução, na literatura, de "[...] manifestações elementares de estruturalidade como as simples repetições, às quais se dava significação interior com o auxilio da técnica dos leitmotivs" (MIELIETINSKI, 1987, p. 351-352).

Em contrapartida, a existência de "mitologismos" diversos se mostra, por exemplo, nas literaturas produzidas por alguns escritores latino-americanos, africanos e asiáticos, as quais não se constituem pela pretensão de ultrapassar o âmbito histórico-social, mas pela comunhão deste com a matéria mitológica, estabelecendo entre eles relações de "complementaridade" (MIELIETINSKI, 1987, p. 354). As tradições míticas ainda são - ou ao menos eram até pouco tempo - um substrato cultural vivo desses países e os motivos mitológicos em suas literaturas se mostram fonte de simbolização para a construção de uma imagem de nação (MIELIETINSKI, 1987, p. 353). Mielietinski (1987, p. 433) é profundamente assertivo ao afirmar que a influência da poética do mito do modernismo europeu na literatura produzida em países considerados periféricos a partir da década de 1950 é inegável, mas que essa ingerência, para se consolidar, teve de ser erguida sobre bases locais ou se mostraria apenas uma tendência passageira. De modo distinto ao que se instaurou no ocidente da Europa, vários romances escritos nesses paises apresentaram as tradições folclórico-mitológicas em convivência com a postura artística do mitologismo do romance europeu e com a recriação literária de sua própria realidade histórica (MIELIETINSKI, 1987, p. 433).

Terra Sonâmbula se insere na tendência investigada por Eleazar Mielietinski ao apresentar a apreensão mitopoética da realidade de guerra civil moçambicana. Com a independência, Moçambique se põe em busca da formação de uma identidade nacional, sobre a qual se propõem debates ainda hoje concernentes à produção literária do país. Tania Macêdo e Vera Maquêa (2007, p. 21) comentam sobre a necessidade de criar-se a nação moçambicana tão almejada durante a sua luta de libertação. No entanto, a falta de unidade política e cultural de Moçambique inibiu a tentativa de construção da imagem da Nação, mesmo que esta seja sempre uma constituição em parte ilusória (MACÊDO; MAQUÊA, 2007, p. 21). Rita Chaves (2005, p. 289) discute a dimensão política reivindicada pela literatura produzida em um país em que a incomunicabilidade, decorrente de uma perversa política de reforço às diferenças entre os seus vários grupos etnolinguísticos, instila nos escritores o esforço de "[...] aglutinar os fragmentos gerados pela História construida numa sequência de cisões". As obras de Mia Couto demonstram o empenho pela discussão dessa questão via diálogo entre a atual Moçambique e as memórias de seu passado. O autor o faz, no entanto, sem maniqueísmos. O aspecto político da obra de Couto não parte de uma visão idealizada das origens do país, mas da compreensão de que fazê-lo seria forjar uma simplificação do processo histórico moçambicano. A interpenetração entre história e mito, em Terra Sonâmbula, não adere, portanto, à exaltação romântica da imagem nacional que, segundo Mielietinski (1987, p. 432), é manifesta 
em algumas obras inseridas na tendência da mitologização do século XX.

A poética do mito no romance de Couto é estabelecida, assim, nos espaços de negociação entre os mundos coexistentes de Moçambique. Carmen Lucia Tindó Ribeiro Secco (2006, p. 72) pontua que

Mitos, ritos e sonhos são caminhos ficcionais trilhados pelas narrativas de Mia Couto que enveredam pelos labirintos e ruinas da memória coletiva moçambicana como uma forma encontrada para resistir à morte das tradições causada pelas destruições advindas da guerra. As úlceras deixadas nas paisagens são deploradas pela escritura mitopoética do autor, cujo lirismo funciona como bálsamo cicatrizante e cuja lucidez política serve para abrir os olhos do povo, numa tentativa de curar a cegueira reinante em Moçambique, nos tempos pós-Independência.

Dessa maneira, o lirismo mitopoético do escritor não é examinado, neste trabalho, de maneira apartada das dimensões históricas e políticas que assume na narrativa, mas voltando-se para elas. Para Bosi (1983, p. 149), a mitopoética se mostra uma elaboração estética esquiva à ordem burguesa, na medida em que esta busca o domínio da natureza e da alma em defesa da ideia de progresso e aquela "....] deplora as úlceras que o dinheiro fez e faz na paisagem [...] e tenta reviver a grandeza heróica e sagrada dos tempos originários, unindo lenda e poema, mythos e epos". A poesia do mito é capaz de responder ao horror do presente pela ressacralização da memória de uma comunidade (BOSI, 1977, p. 150) e reinventar imagens de uma unidade perdida como meio de resistência às contradições históricas (BOSI, 1977, p 155).

É preciso não perder de vista, no entanto, que, ao ser constituida como organização narrativa e descrição simbólica da sociedade moderna, a mitopoética tece paralelos com os mitos tradicionais transformando-os em grande medida (MIELIETINSKI, 1987, p. 441). Do mesmo modo que Couto não busca escrever o passado em sua integridade, em Terra Sonâmbula, como forma de enaltecê-lo, também não o faz com o resgate dos mitos e da tradição oral moçambicanos. Logo, a linguagem mitopoética é elaborada por meio da reformulação dos elementos que mar- cam a Moçambique perdida com a exploração colonial e não da restauração exata deles. Dessa maneira, o estudo da literatura do país não deve ser sustentado pela dicotomia entre oralidade e escrita, gêneros de matriz africana e gêneros de origem ocidental. Sobre a intertextualidade que a literatura contemporânea de Moçambique apresenta com a sua tradição oral, Ana Mafalda Leite (1998, p. 33) salienta que

\begin{abstract}
A enunciação do legado "oral" faz-se através do enunciado, que cumula e concentra, numa geologia estratificada que atinge a sintaxe. os ritmos hibridos das "oralidades". É neste trabalho da "língua" como texto (na acepção kristeviana) que se desvelam as "tradições" traidas, e reformuladas, e se recuperam os traços genológicos de variadas "formas" ou "géneros" orais africanos, e outros géneros provenientes da literatura escrita.
\end{abstract}

A língua portuguesa de Couto já não se configura, portanto, como o idioma opressor da metrópole europeia, mas como uma "filha rebelde, mas domável, permeável a outras línguas" (MACÊDO; MAQUÊA, 2007, p. 22). Os seus romances não instauram uma relação de violência para com os gêneros nativos africanos, mas constroem um espaço de intersecção entre gênero de tradição ocidental e oralidade da cultura tradicional moçambicana (MACÊDO; MAQUÊA, 2007, p. 56).

Fernanda Cavacas (2006, p. 67) aponta os principais aspectos da escrita de Couto conjugados na composição de um novo discurso literário que consegue encarnar a multiplicidade cultural de Moçambique na contemporaneidade: o léxico reinventado pelo entrelaçamento entre língua portuguesa moçambicana e outras que com ela convivem; a afinidade entre oralidade e organização morfossintática do discurso; o discurso polifônico na ironia; os recursos estilísticos da imagética coutista (metáfora, perifrase); e outros elementos recorrentes em sua estética, como a cadência das sentenças, o uso do pretérito mais-que-perfeito, a particularidade de sua adjetivação e o emprego de diminutivos com traços semânticos diversos. Mediante esses aspectos e muitos outros, Mia Couto desenvolve, em Terra Sonâmbula, uma engenharia poética do mito assentada no contexto histórico atual e pretérito de sua nação. 
É o que ocorre quando, por exemplo, as memórias de Kindzu, em sua riqueza e fragilidade, são Lidas por Muidinga, enquanto Tuahir recorda o seu antigo emprego no comboio e limpa o interior do ônibus queimado:

\author{
- Me lê, miúdo. Vai lendo enquanto eu faço \\ um serviço.
}

Então o velho improvisa um xipefo, solta um pano vermelho. Apanha um ramo de palmeira e inventa uma vassoura. Varre o interior do machimbombo enquanto canta. O miúdo desfolha os cadernos sorridente. O velho se recriava igual ao seu antigo emprego. E é como se o próprio Muidinga estivesse sentado na estação, aguardando o próximo comboio. Tuahir vai juntando os residuos do queimado numa velha tampa. Depois, sai do autocarro e espalha as cinzas pelas terras em volta.

- O que está a fazer, tio?

- Estou para semear este adubo. É para amanhã quando chover. Continue filho. Não pare de ler (COUTO, 2007, p. 139, grifo do autor).

A leitura das reminiscências de Kindzu por Muidinga se junta às recordações encenadas de Tuahir, resultando nos resíduos do ônibus queimado - os rastros pelos quais, segundo Gagnebin (2006, p. 42), o passado pode ser apreendido -, semeados por Tuahir à espera da chuva, no compasso da esperança para a construção de um futuro outro. A importância da recitação e da reatualização do mito cosmogônico para a instauração de um Mundo simbolicamente refeito em algumas sociedades arcaicas, sobre a qual comenta Eliade (2013, p. 27), se mostra análoga à urgência da leitura das memórias de Kindzu e à encenação de Tuahir sobre o seu passado, que devolvem ao menino e ao velho a chance de sonhar. A imagem é visceral: não é cultivada a semente, portanto, mas o adubo retirado das cinzas provenientes da guerra e da memória; não se semeia a possibilidade do fruto, mas sim da própria fertilização da terra moçambicana. Ainda é preciso, no entanto, que a chuva do amanhã caia sobre as cinzas do ontem, disseminadas no agora. A chuva completa, assim, a constelação entre passado, presente e futuro mediante a qual se poderia construir uma Moçambique frutificada pela palavra. Essa imagem de Couto - articulada, por exemplo, à polissemia no uso do pronome em "Me lê", ao neologismo "desfolhar" e à voz reflexiva em "O velho se recriava" - demonstra como o emprego da mitopoética no romance passa pela necessidade ética de apreender-se o real por uma linguagem que costura os tempos, tensionando-os, e não se resvalando em um lirismo descomprometido com a realidade histórica do país. Para Secco (2006, p, 77) as "letras do sonho" nunca perdem de vista, em Mia Couto, o enfoque social e filosófico da história, cambiando-se em olhar crítico de combate ao horror e criando um horizonte de possibilidades para um povo cujas vistas do devir é nublada pela barbárie da guerra.

Macêdo e Maquêa (2007, p. 40) consideram a morte e a convivência entre vivos e mortos como uma temática recorrente da literatura de lingua portuguesa moçambicana. Segundo as pesquisadoras, o tema sugere a estreita relação da produção literária de Moçambique com a cosmogonia africana (MACÊDO; MAQUÊA, 2007. p. 41). A partir dos mitos cosmogônicos do continente, viabiliza-se uma "concepção de força vital presente em todos os seres e que não se extingue com a morte, antes ganha uma nova maneira de ser", de modo a permitir o contato entre o mundo dos vivos e o dos mortos (MACÊDO; MAQUÊA, 2007, p. 43). Essa tópica constante se mostra, no romance de Couto, pelo encontro entre as duas margens da existência, concretizado com, por exemplo, a morte de Taímo, pai de Kindzu, e a sua persistência em segui-lo durante a viagem do jovem. O contato entre pai e filho, vida e morte, é anunciado já com o sepultamento de Taímo:

Cerimónia fúnebre foi na água, sepultado nas ondas. No dia seguinte, deu-se o que de imaginar nem ninguém se atreve: o mar todo secou, a água inteira desapareceu na porção de um instante. No lugar onde antes praiava o azul, ficou uma planície coberta de palmeiras. Cada uma se barrigava de frutos gordos, apetitosos, luzilhantes. Nem eram frutos, parecia eram cabaças de ouro, cada uma pesando mil riquezas. Os homens se lançaram nesse vale, correndo de catanas na mão, no antegozo daquela dádiva. Então se escutou uma voz que se multiabriu em ecos, parecia que cada palmeira se servia de infinitas bocas. Os homens ainda paravam, por brevidades. Aquela voz seria em sonho que figurava? Para mim não havia dúvidas: era a voz de meu pai. Ele pedia que 
os homens ponderassem: aqueles eram frutos muito sagrados. Sua voz se ajoelhava clamando para que se poupassem as árvores: o destino do nosso mundo se sustentava em delicados fios. Bastava que um desses fios fosse cortado para que tudo entrasse em desordens e desgraças se sucedessem em desfile. O primeiro homem, então, perguntou à árvore: por que és tão desumana? Só respondeu o silêncio. Nem mais se escutou nenhuma voz. De novo, a multidão se derramou sobre as palmeiras. Mas quando o primeiro fruto foi cortado, do golpe espirrou a imensa água e, em cantaratas, o mar se encheu de novo, afundando tudo e todos (COUTO, 2007, p. 20-21)

O espaço em que o rito fúnebre se dá está relacionado ao motivo pelo qual, no fim da narrativa, Muidinga quer ver o mar. Para ele, "[...] era como se o mar, com seus infinitos, lhe desse um alivio de sair daquele mundo [...]" (COUTO, 2007, p. 174). No entanto, o sepultamento resulta no esvaziamento, no dia seguinte, das águas marítimas, substituidas por palmeiras com faustosos frutos. O comando da voz misteriosa, que Kindzu supõe ser a de seu pai, e a desobediência dos moradores da vila fundem cosmologia africana com mito fundador cristão. Todavia, não há uma macieira, mas palmeiras; o fruto não é aquele do conhecimento sobre todas as coisas, mas o do sustento corporal e onírico da prosperidade futura. E isso se dá por meio de uma linguagem cujo aspecto oral se reinventa pela escritura das memórias de Kindzu, edificada, entre outros recursos, pela criação dos verbos "praiar", "barrigar", "multiabrir"; pela hipálage em "pesando mil riquezas"; e pela expressão paradoxal "espirrou a imensa água".

O universo dos mortos é também matéria abordada no episódio em que Kindzu se encontra nas areias de Tandissico, "onde o mar se abre como uma palavra azul" (COUTO, 2007, p. 41):

Foi quando, num súbito, vi uma mão sair da terra. Subiu no espaço e, avançando no desajeito de um cego, me agarrou a perna. Tombei, gritando. Consegui me soltar. Depois, levantei e corri pelo areal até me esgotar. Parei, caí sobre os joelhos e despejei em mim todo o cantil.

Melhorei, deixei de tremelejar? Nem hoje ainda sei? Como posso segurar essa lembrança sem estremecer? Pois, daquele areal foram saindo outras mãos, mãos e mais mãos. Pareciam estacas de carne, os dedos remexendo com desespero de passaritos pedindo comida. Confesso: naquele momento, chorei, igual uma criança.
Fiquei nesse prantochão até que o cheiro de passos me chegou. Levantei os olhos: ele ali estava! Nem eu posso trazer o recordo dessa figura. Suas formas não figuravam um desenho de descrever, semelhando um malfeitor vindo dos infernos. Sempre eu só ouvira falar deles. os psipocos, fantasmas que se contentam com nossos sofrimentos. Ali estava um deles, inteiro de sombra e fumo (COUTO, 2007, p. 41).

A imagem dos mortos se reerguendo da terra em direção a Kindzu pode nos remeter à tese seis de "Sobre o conceito de História", de Walter Benjamin, na qual o autor afirma que o historiador - e acrescentamos aqui, por nossa conta, o escritor de literatura -, ao reacender no passado a faísca da esperança, precisa possuir como perspectiva a certeza de que nem os mortos estarão a salvo caso o cortejo do progresso vença (BENJAMIN, 1994. p. 224-225). Se, por um lado, os mortos renascem a Kindzu, trazendo com eles as suas atormentadas memórias da guerra, por outro, o jovem passa a ter acesso ao mundo mortuário por uma espécie de rito iniciático. Sobre isso, Tutikian e Silva (2003, p. 91-92) argumentam que

\begin{abstract}
Se o inferno está povoado de almas, espécie de duplos imateriais ou sombras dos seres vivos, levando uma vida larvar num mundo de brumas, atormentada pela memória da vida terrestre, conhecê-lo, ainda que como um grande pesadelo e vencê-lo, pelo conhecimento do segredo das coisas, confirma um estatuto heróico e mítico num modelo de procura iniciática. Esse é um aspecto muito forte numa cultura mítica, quando a ruptura com o real não é criada, mas trazida à ficção na transposição da própria cultura, numa espécie de linguagem adequada à descrição de modelos eternos de comportamento, de certas leis essenciais do cosmo social e natural [...].
\end{abstract}

A análise das autoras é pertinente na medida em que se fundamenta na concepção de que o mito não é constituido como alegoria ou símbolo, uma vez que se reporta ao destino humano e cosmológico (TUTIKIAN; SILVA, 2003, p. 92). Segundo Mielietinski (1987, p. 9), a alegorização do mito se instaurou a partir da tentativa de interpretação racional da narrativa mitológica, perspectiva que não ocupava o horizonte das sociedades regidas pelo pensamento mítico. No entanto, a presença de imagens da ordem do insólito, em Terra Sonâmbula, já não recupera 
somente o mito tradicional africano, mas a sua modificação pelas culturas a ele articuladas. Dessa forma, o apontamento da dimensão simbólica e metafórica da mitopoética de que vale Couto não se mostra, ao nosso ver, como uma injúria ao conteúdo "essencial" do mito.

Em meio à viagem mítica realizada tanto por Kindzu quanto por Muidinga e Tuahir, os episódios acerca da lição Siqueleto, do fazedor de rios e das velhas profanadoras apresentam personagens que assumem a imagem da ancestralidade, da tradição e, ao mesmo tempo, da expectativa de uma nova Moçambique. Siqueleto se entrega à natureza e incorpora-se ao movimento cíclico do mito-ritual cósmico africano; Nhamataca, ao dedicar-se à construção de um rio que costura suas duas margens, corporifica o sonho utópico do país; as idosas, ao violentarem Muidinga, encarnam o embate entre o ancestral e o contemporâneo (TUTIKIAN; SILVA, 2003, p. 88-89). Outros trechos de Terra Sonâmbula poderiam ser examinados frente à formulação estética de posicionamento ético que a linguagem mitopoética, dentre outros elementos, assume no romance. Atentamo-nos, neste artigo, a alguns fragmentos que nos pareceram particularmente relevantes.

Andréa Vilela Gouvêa Quadra e Raquel Costa Chaves (2004, p. 141) ressaltam a tensão criada por Mia Couto, em Terra Sonâmbula, entre a tradição e a "cultura nova" de Moçambique. As pesquisadoras afirmam, porém, que há, no romance, a tentativa de delineamento de um modelo de nação que sintetize harmonicamente a multiplicidade cultural do país. Apostamos, por meio deste estudo, em uma perspectiva bastante distante da apresentada por Quadra e Chaves, tendo em vista que procuramos demonstrar como Mia Couto não recorre a uma síntese conciliadora das fronteiras que dilui, colocando-as, pelo contrário, em espaço de confronto sem dali retirá-las. O escritor abre a ferida da história e a deixa aberta, vertendo o sangue da barbárie cuja memória pode proporcionar um futuro que dela difere. Nesse sentido, o trecho a seguir condensa a proposta literária de Couto que buscamos evidenciar nesta pesquisa:
Pensava sobre as semelhanças entre mim e Farida. Entendia o que me unia àquela mulher: nós dois estávamos divididos entre dois mundos. A nossa memória se povoava de fantasmas da nossa aldeia. Esses fantasmas nos falavam em nossas línguas indigenas. Mas nós já só sabiamos sonhar em português. E já não havia aldeias no desenho do nosso futuro (COUTO, 2007, p. 92-93).

Pelo resgate dos mitos tradicionais e sua acentuada modificação por uma sociedade moçambicana que já não é aquela que os originou, a linguagem mitopoética se mostra uma estética de escrita literária da história que sugere a dissolução e o tensionamento entre mito e história, oralidade e escrita, poesia e prosa e língua portuguesa e línguas moçambicanas. A poética do mito assume, assim, um caráter estético ético por não ser instrumento de enaltecimento ingênuo do continente africano, mas por exercer a função do rio de Nhamataca, costurando duas margens aparentemente opostas, ou, ainda, atuando como o oceano índico de Surendra, que converte este, indiano, e Kindzu, moçambicano, em uma só etnia, a índica, sem, contudo, promover o apagamento de suas particularidades irredutiveis.

A mitopoética é constituida, em Terra Sonâmbula, como uma linguagem que contrabandeia certa Moçambique reinventada metonimicamente nos espaços de dois planos narrativos particulares, mas que se desdobram em dimensões cada vez mais abertas no decorrer do enredo. O mau presságio anunciado por Assane, antigo secretário do administrador de uma cidade em que Kindzu se instala, não se aplica apenas aos moçambicanos, mas a todos nós que persistimos em seguir no cortejo triunfal do progresso: "[...] a História há-de limpar os pés nas nossas costas" (COUTO, 2007, p. 57, grifo do autor).

\section{Referências}

ADORNO, Theodor W. Arte, sociedade, estética. In: ADORNO, Theodor W. Teoria estética. Tradução Artur Morão. Lisboa: Edições 70, 2011. p. 11-33.

ADORNO, Theodor W: HORKHEIMER, Max. Dialética do esclarecimento: fragmentos filosóficos. Tradução Guido Antonio de Almeida. Rio de Janeiro: Jorge Zahar, 1985. 
BENJAMIN, Walter. Sobre o conceito de história. In: BENJAMIN, Walter. Magia e técnica, arte e politica: ensaios sobre literatura e história da cultura. Tradução Sergio Paulo Rouanet. 7. ed. São Paulo: Brasiliense, 1994. p. 222-232. (Obras escolhidas; v. 1)

BOSI, Alfredo. Poesia Resistência. In: BOSI, Alfredo. O ser e o tempo da poesia. São Paulo: Cultrix, 1983. p. 141-192.

CERTEAU, Michel de. A escrita da história. Tradução Maria de Lourdes Menezes. 3. ed. Rio de Janeiro: Forense Universitária, 2015

CHAVES, Rita. Angola e Moçambique: experiência colonial e territórios literários. São Paulo: Ateliê, 2005.

CAVACAS, Fernanda. Mia Couto: palavra oral de sabor quotidiano/palavra escrita de sabor literário. In: CHAVES, Rita; MACÊDO, Tania (org.). Marcas da diferença: as literaturas africanas de lingua portuguesa. São Paulo: Alameda, 2006. p. 57-73

COUTO, Mia. Terra Sonâmbula. São Paulo: Companhia das Letras, 2007.

ELIADE, Mircea. Mito e realidade. Tradução Pola Civelli. 6. ed. São Paulo: Perspectiva, 2007. (Coleção debates; 52 / dirigida por J. Guinsburg)

GAGNEBIN, Jeanne Marie. Lembrar escrever esquecer. São Paulo: Ed. 34, 2006.

GINZBURG, Jaime. Escritas da tortura. In: TELES, Edson; SAFATLE, Vladimir (org.). O que resta da ditadura: a exceção brasileira. São Paulo: Boitempo, 2010. p. 133-149.

GINZBURG, Jaime. Literatura e violência. In: GINZBURG, Jaime. Literatura, violência e melancolia. Campinas: Autores Associados, 2012. p. 15-45.

LEITE, Ana Mafalda. Empréstimos da oralidade na produção e críticas literárias africanas. In: LEITE, Ana Mafalda. Oralidades e escritas nas literaturas africanas. Lisboa: Edições Colibri, 1998. p. 11-36.

LÉVI-STRAUSS, Claude. Quando o mito se torna história. In: LÉVI-STRAUSS, Claude. Mito e significado. Tradução António Marques Bessa. Lisboa: Edições 70 , 1978. p. 42-52.

LÖWY, Michael. Walter Benjamin: aviso de incêndio uma leitura das teses "Sobre o conceito de história". Tradução Wanda Nogueira Caldeira Brant; tradução das teses: Jeanne Marie Gagnebin e Marcus Lutz Müller. São Paulo: Boitempo, 2005.

MACÊDO, Tania; MAQUÊA, Vera. Literaturas de Lingua Portuguesa: marcos e marcas - Moçambique. São Paulo: Arte \& Ciência, 2007.

MIELIETINSKI, Eleazar M. A poética do mito. Tradução Paulo Bezerra. Rio de Janeiro: Forense, 1987.

PATAI, Raphael. Mito e história. In: PATAI, Raphael. O mito e o homem moderno. Tradução Octavio Mendes Cajado. São Paulo: Cultrix, 1974. p. 67-78.

QUADRA, Andréa Vilela Gouvêa; CHAVES, Raquel Costa. Sonhando Moçambique. Revista do Centro de Estudos Portugueses, Belo Horizonte. v. 24. n. 33. jan./dez. 2004. https://doi.org/10.17851/2359-0076.24.33.141-151.
SECCO, Carmen Lucia Tindó Ribeiro. Mia Couto: o outro lado das palavras e dos sonhos. Via Atlântica, São Paulo. n. 9. p. 71-84, jun. 2006. https://doi.org/10.11606/ va.voig. 50041

TUTIKIAN, Jane; SILVA, Vivian Ignes Albertoni. Viagem para lembrar o esquecimento de um povo ou o desatento abandono de si (um estudo de Terra Sonâmbula de Mia Couto). Organon, Porto Alegre. v. 17. n. 34. p. 83100, 2003. https://doi.org/10.22456/2238-8915.29977.

\section{Fabiana Nicoli Dias}

Graduanda em Língua Portuguesa e Literaturas de Lingua Portuguesa pela Universidade Federal do Espírito Santo (UFES), em Vitória, ES, Brasil.

\section{Fabíola Simão Padilha Trefzger}

Doutora em Letras: Estudos Literários pela Universidade Federal de Minas Gerais (UFMG), em Belo Horizonte, MG, Brasil; professora da Universidade Federal do Espírito Santo (UFES), em Vitória, ES, Brasil.

\section{Endereço para correspondência}

Fabiana Nicoli Dias

Av. Resplendor, 95, ap. 303, Ed. Costa Verde

Itapuã, 29101521

Vila Velha, ES, Brasil

Fabiola Simão Padilha Trefzger

Rua Eurico de Aguiar, 120, ap. 504, Ed. Maison du Soleil Praia de Santa Helena, 29055280

Vitória, ES, Brasil 